\title{
Enduring symbols of dentistry: international metaphors of dental science
}

- Enables practitioners to 'read' the icons and symbols used to identify the profession of dentistry.

- Enriches professional life by the immediacy of the history of dentistry.

- Adds an extra aesthetic dimension to clinical and scientific life.

\author{
J. Pearn
}

Dentists' contributions to science and society extend beyond the practice of clinical dentistry and preventive oral health. Such service encompasses contributions to biology specifically and more generally to societal good works for which dentists are particularly esteemed. The profession of dentistry promotes the history and heritage of its craft and those who practise it. Enduring symbols of dentistry take many forms. These include metonymic emblems such as those of Cadmus and Saint Apollonia and the portrayal of effigies of twentieth century dentists on eponymous medals. Other enduring symbols are to be found in the names of streets and towns (eg Normanville in Australia) which commemorate dentists; and in the worldwide scientific names of plants and animal species which perpetuate singular contributions of dentists to biological science. Such include the scientific names of grasses (Deyeuxia rodwayi) after the Tasmanian dentist, Dr Leonard Rodway (1853-1936); seaweeds (Jeannerettia sp.) after a seaweed of the Pacific and Southern Oceans, after Dr Henry Jeannerett (1802-1886); gastropods (Typhina yatesi) after Dr Lorenzo Yates (1837-1909); copepods (eg Mimocalanus heronae) named to commemorate the life and works of Gayle Ann Heron (b.1923), a dental hygienist of the University of Washington, USA; and crabs (eg Cancer bellianus) named to commemorate the life and works of the leading British dentist of his day, Thomas Bell (1792-1880). This paper explores this theme of the creation and promotion of enduring symbols of dental science - enshrined in the civic, numismatic and taxonomic record.

\section{Introduction}

A profession is defined as a corpus of knowledge and skills, offered for the betterment or enjoyment of people rather than things, in which high standards are set. The protection and integrity of such standards are in turn jealously guarded by its practitioners. A profession develops ethical codes which enjoin its members, and promotes and displays symbols of its history and heritage.

The profession of dentistry has many such symbols of its craft. They engender the continuity of identity in a professional world where knowledge changes constantly and where practitioners come and go, and where physical buildings and collegiate institutions disappear.

Professor, Department of Paediatrics \& Child Health, Royal Children's Hospital, Herston, QLD 4029, Australia Correspondence to: Professor John Pearn Email:j.pearn@uq.edu.au

\section{Refereed Paper}

Accepted 2 September 2008

DOI: 10.1038/sj.bdj.2008.1028

${ }^{\bullet}$ British Dental Journal 2008; 205: 615-621
The symbols of dentistry comprise an enduring legacy in which are embedded facets of heritage; milestones along the developmental path of the profession; memorials to the lives of former practitioners; and metonyms of the highest ideals of that best-practice to which the profession aspires.

In this paper I give examples of four classes of enduring symbols of dentistry - the badges which we wear; the logos with which we embellish our written and electronic texts; the medals which we bestow as symbols of esteem; and the scientific names we create to record the lives and works of those who have gone before.

\section{Dental metonyms}

A metonym is an identifier which evolves to symbolise a primary object. In the health sciences, the Aesculapian serpent is the metonym of curative medicine, the residual symbol of the more extensive and formal portrayal of the god of medicine, Aesculapias, always shown

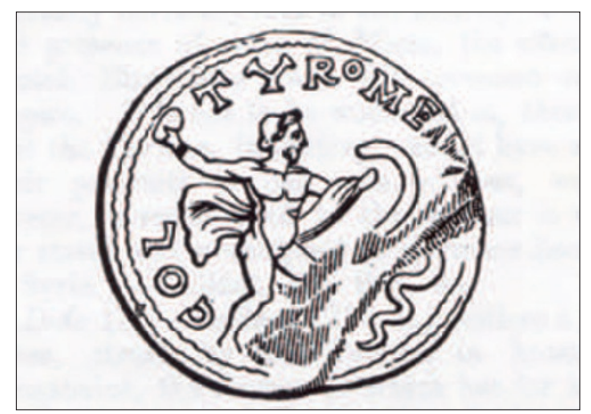

Fig. 1 A coin of ancient Tyre, showing Cadmus slaying a dragon. This coin was struck and issued in the reign of the Roman emperors Licinius Egnatius Gallienus (in 253 AD) and Gordian III (238-244 AD)

holding his staff with its entwined serpent. In dentistry, the principal Western referents, dating from the era of classical Greece and later from Rome, comprise the legends of Cadmus; ${ }^{1}$ and later the sanctification of Saint Apollonia, the Patron Saint of Dentists. ${ }^{2}$ In other cultures, different symbols portray the concept of dental health. The Indian Army Dental Corps, for example, uses the metaphor of crossed elephant tusks, enjoining both the Ancient Sanskrit and 


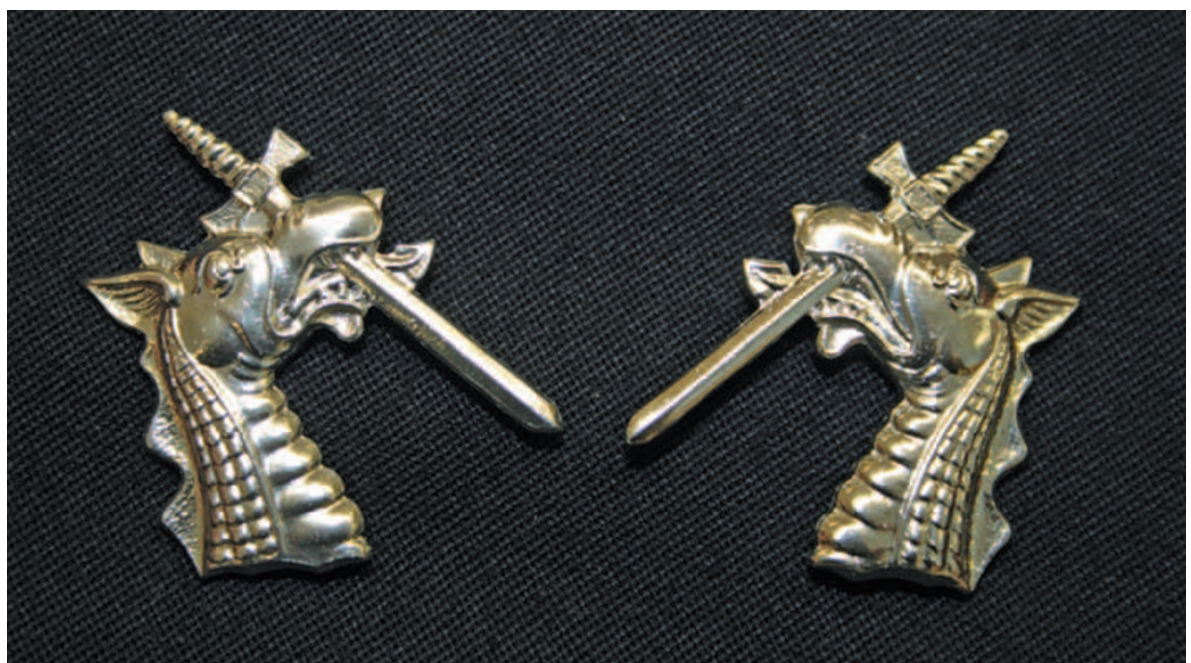

Fig. 2 The Boeotian dragon, slain by Cadmus with his sword. This metonymic portrayal of dentistry is used in many logos. Illustrated are the formal-wear silvered lapel emblems of the Royal Australian Army Dental Corps

Hindu sacredness of elephants with the powerful symbol of strong, albeit modified, upper incisor teeth.

\section{Cadmus}

Universal symbols of dentistry are the metonyms of Cadmus who slew the Boeotian dragon and founded the ancient Greek city of Thebes (Fig. 1). These often-used symbols comprise the Theban dragon and the sword, which one form of the legend has it was the weapon with which Cadmus slew the dragon (Fig. 2). Many who have served in the Military Dental Corps of nations of the British Commonwealth have worn the Cadmean emblems of this ancient Greek legend (Fig. 3).

Cadmus first appeared in the Homeric Odyssy (Od.5.333), as the father of the goddess, Ino-Leucothea. ${ }^{1}$ Cadmus was the brother of Europa, who had been abducted by Zeus. In seeking her, Cadmus travelled extensively and consulted the pythoness oracle at Delphi, in central Greece. Her counsel was for Cadmus to be guided by a cow and establish a new city where the animal lay down. Unfortunately, the cow did so in a region ruled by a dragon, which Cadmus slew. One account details the action:

Cadmus flung his spear so straight and strong that black blood gushed from the dragon's breast to mingle with the foam of its fury. Now it uncoiled all its monstrous length, and issuing from its cave, reared its horrid heads like trees to fall upon the man who dared to face its wounded rage. But Cadmus held his ground, smiting with all his might at the firey jaws, until he drove sword through one poison-swollen throat to an oak trunk....all unhurt, Cadmus stood over the dead body, when he became aware of Pallas Athene at his side, come down from Olympus to found a city that should grow great under her aegis.

'Sew the dragon's teeth in the earth' she bid him. 'From them will spring up a race of war-like men to do thy will'.

Much wondering at such counsel, Cadmus did not disobey. He dug deep furrows with his sword; and he plucked out the dead dragon's teeth; and he sewed them in the earth drenched by its gore. Forthwith the ground began to heave and swell and bristle with spear points; and quickly there sprang up a crop of armed men, their weapons clashing together like a corn beaten by the wind. ....no sooner were the new-born warriors full grown out of their furrows, they fell upon each other in their lust for battle. So fiercely they fought that, before the sun was set, all but five had fallen dead on the bosom of their mother earth. These five, weary with blood shed, dropped their weapons and offered themselves to serve Cadmus in a place of his followers slain by the dragon... with their aid he built the city that came to be called Thebes... ${ }^{3}$

The warriors who sprang from the dragon's teeth were the Spartoi, their descendents identified by a birthmark in the shape of an arrowhead. ${ }^{4}$

The Royal Australian Army Dental Corps' Cadmean emblem (Fig. 2) is derivative from the Royal Army Dental Corps insignia, a fine example of both

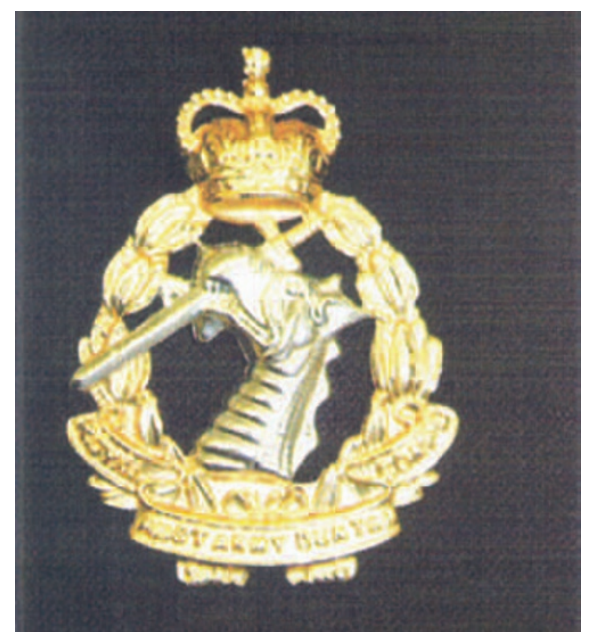

Fig. 3 The insignia, with the Boeotian dragon slain by Cadmus, at the enwreathed centre of the badge of the Royal Australian Army Dental Corps

the universality of such metonyms and their enduring continuity. The Australian Army Dental Corps was formed on the 23 April $1943 .^{5}$

\section{Scientific names}

When Linnaeus published his taxonomic system of living things in 1758, in the tenth edition of Systema Naturae $^{6}$ he completed the system of biological nomenclature which is used today. This not only brought order to the classification of plants and animals, but established the system of scientific memorialisation, by which the names of worthy scientists might be perpetuated.

One of the first dental surgeons to have his name recorded in a scientific species was Thomas Bell (1792-1880), the leading British dentist of his day ${ }^{7}$ who was also a leading zoologist. A species of Australian goanna, the 'Football Jersey' strain of the Australian Lace Monitor, was named Varanus belli, or Bell's Monitor, in his honour in $1836 .{ }^{8}$ In 1790 , Surgeon General John White, the Surgeon General of the First Fleet from 1788, had named the holotype (now presumed lost) of the Lace Monitor, Varanus varius, from New South Wales. ${ }^{8}$ Varanus belli is today sunk as a junior synonym.

Thomas Bell was born in Poole, Dorset and served as the Senior Dental Surgeon at Guy's Hospital in London for almost all his professional career (1817-1861). He was also a leading zoologist and in addition to his dental appointment at Guy's Hospital, was concurrently appointed Professor of Zoology at King's College, 
London, from 1836. An anti-Darwinian, his specialty was reptiles, especially tortoises and snakes. His magnum opus was Monograph of the Testudinata, the first eight parts of which were issued from 1832 to 1842 . It was never finished, owing to his publisher's bankruptcy. In 1838-39, Thomas Bell published the first complete edition of History of British reptiles. ${ }^{7}$ Many dentists have their names perpetuated in both native botanical species and in horticultural cultivars. ${ }^{9-13}$

\section{British dentists' names in Australian plants}

The first dentists to practise in Australia, all from 1818, were Simon Lear, Ambrose Foss and George White. ${ }^{9}$ The author of the first published work on dentistry (1830) in Australia ${ }^{10-12}$ was Dr Henry Jeannerett, another pioneer colonial dentist who worked both in Sydney and in Van Diemen's Land. ${ }^{13}$

\section{Dr Henry Jeannerett (1802-1886)}

Henry Jeannerett was Australia's first specialist dentist as the term is understood today (Fig. 4). His living memorial is a beautiful genus of seaweeds, Jeannerettia, which flourish in the waters of the Southern Ocean. Henry Jeannerett was born in London on New Year's Eve, 1802. At the age of 15 he was apprenticed as a surgeon in Oxford. He later studied at the Radcliffe Infirmary in Oxford; and at the London Hospital and the City Dispensary in London and in Paris. In 1824 he was awarded his Licentiate of the Society of Apothecaries. He was an enthusiastic naturalist and in 1825 was elected as President of the Plinian Natural History Society.

Jeannerett lead a turbulent life in Australia. He emigrated on the brig Tranmere to Van Diemen's Land in 1829. Initially disillusioned with conditions at the convict settlement there he moved to Sydney where he practised both as a dentist and a doctor. His 1830 book, entitled Hints for the preservation of the teeth,$^{10}$ was favourably reviewed in the Sydney Gazette. ${ }^{14}$ Oral ill health, both dental and gingival, was a major scourge of the Colony. Oral infection, pain and disability afflicted both free immigrants and convicts alike, as well as the soldiers who guarded them.
In 1834, Jeannerett and his wife moved again to Hobart where he practised both as a doctor and a dentist. It was there that Jeannerett became particularly interested in botany and it was from Port Arthur that he sent his first specimens of both land and sea plants to the British Museum and the Dublin Herbarium. ${ }^{15}$

In 1842 Henry Jeannerett was appointed as Commandant, Surgeon and Justice of the Peace at the Aborigines' Establishment on Flinders Island in Bass Strait. It was a tragic appointment which was to be his professional undoing and the cause of enormous personal anguish over the ensuing 15 years. ${ }^{16}$ In 1850 , Jeannerett left Hobart and Australia for ever, resuming a vigorous clinical life as a dentist in London. He published pamphlets and continued his battles against bureaucracy to obtain personal and public redress for what he saw as his unjust treatment in Van Diemen's Land.

Jeannerett's turbulent life in the colonial administration of Tasmania overshadows somewhat his contributions to dentistry and to botany. His memorial is in the beautiful and delicate red seaweed, Jeannerettia, ${ }^{17}$ which is found commonly in the tidal drift of the southern oceans (Fig. 5). In the original description of this genus in Nereis Australia or 'Algae of the Southern Ocean', Professor William Henry Harvey, surgeon and Curator of the Herbarium of Trinity College in Dublin, noted that:

...this new genus is dedicated by $\mathrm{Dr}$ Hooker and myself, to Dr Jeannerett of Tasmania, from whom we have received a number of interesting Algae, gathered at Port Arthur, among them the first specimens we have seen of this remarkable plant. ${ }^{18}$

\section{Dr Frank Tratman (1860-1926)}

Dr Frank Tratman was the sole medical practitioner at Carnarvon and later at Guildford (from 1886) in Western Australia. He practised also as a dentist. ${ }^{19} \mathrm{He}$ later served as President of the Dental Board of Western Australia. ${ }^{20}$

Frank Tratman was born in Bristol, England, and went to the Bristol Grammar School where he had a distinguished school record. He studied medicine at The London Hospital and after graduation was appointed House Surgeon at

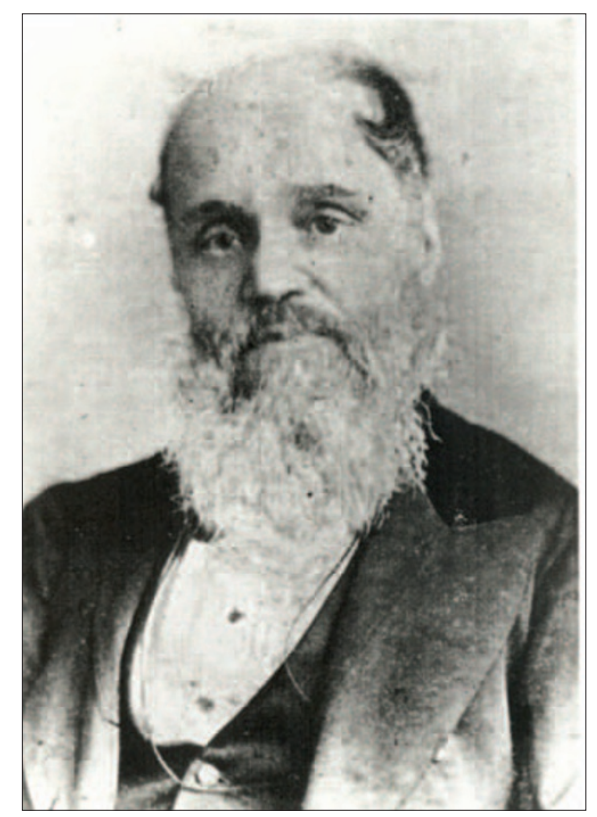

Fig. 4 Dr Henry Jeannerett (1802-1886), Australia's first specialist dentist. In 1830 he published the first text on dentistry in Australia, entitled Hints for the preservation of the teeth. Photograph courtesy of Mr Colin Jeannerett of Hobart, with acknowledgements

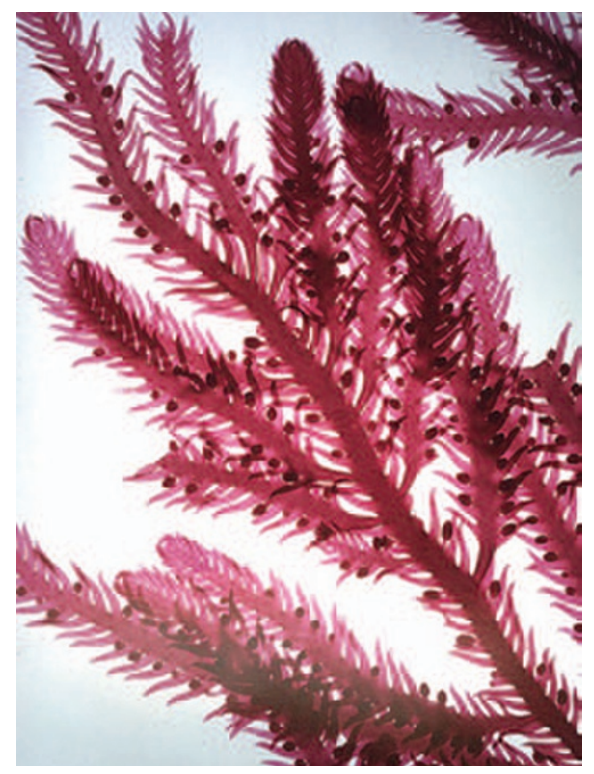

Fig. 5 The Southern Ocean seaweed, Jeannerettia lobata, which commemorates the life and work of the dentist and doctor of Van Diemen's Land, Dr Henry Jeannerett (1802-1886). Photograph courtesy of Dr Bruce Fuhrer, with acknowledgements

that hospital. Tratman worked at Guildford in Western Australia for five years. In his post as the sole government's health officer he became interested in public health and preventive medicine. He also became interested in contagious diseases and their prevention, was awarded the degree of Doctor of Medicine from London University, and was one of the early recipients of the newly 
established Diploma of Public Health. His new training was immediately to be put to great practical use. In 1892, a cholera epidemic swept Russia and Germany, and a quarantine barrier was erected to prevent its spread across the English Channel. Frank Tratman took a significant role in this action which indeed was successful in that England was spared the epidemic. ${ }^{21}$

Two fine Australian native trees are his enduring memorials. They are Tratman's Wattle, Acacia tratmaniana and Tratman's Kerrawang, Rulingia tratmanii. ${ }^{19}$

\section{Leonard Rodway (1853-1936)}

Leonard Rodway was one of the most celebrated dentist-naturalists. ${ }^{22}$ Born in Torquay he served on the Royal Navy Training Ship Glouster for two years. Ill health precluded a career in the Royal Navy and he embarked on a dental career. ${ }^{23}$ He emigrated to Australia in 1890 and practised as a dentist for the ensuing 30 years. For many years Rodway was Secretary of the Dental Board of Tasmania. ${ }^{24}$

His passion was botany. He was the (unpaid) Government Botanist of Tasmania from 1896 to $1932 .{ }^{23}$ He was the Director of the Herbarium in the Tasmanian Museum and a Trustee of the Hobart Botanical Garden. For his services to botany he was awarded the Clarke Medal of the Royal Society of New South Wales. He was also awarded the Royal Society Medal of the Royal Society of Tasmania and decorated C.M.G. for his services to botany.

Leonard Rodway wrote articles on botany, astronomy and zoology. His two greatest works were the encyclopaedic The Tasmanian Flora (Fig. 6), published in $1903^{25}$ and The Mosses of Tasmania, published in 1912 and 1913. The Kew Bulletin of 1936, in an obituary to Leonard Rodway, recorded:

To him, Tasmania owes almost entirely its Herbarium, which he had built up by his own unaided and devoted efforts during the many years he served without any salary as Government Botanist. The Herbarium, though consisting mainly of single specimens of each species, is very well preserved and all the specimens are well mounted, unlike most of those in other Australian Herbaria. ${ }^{23}$

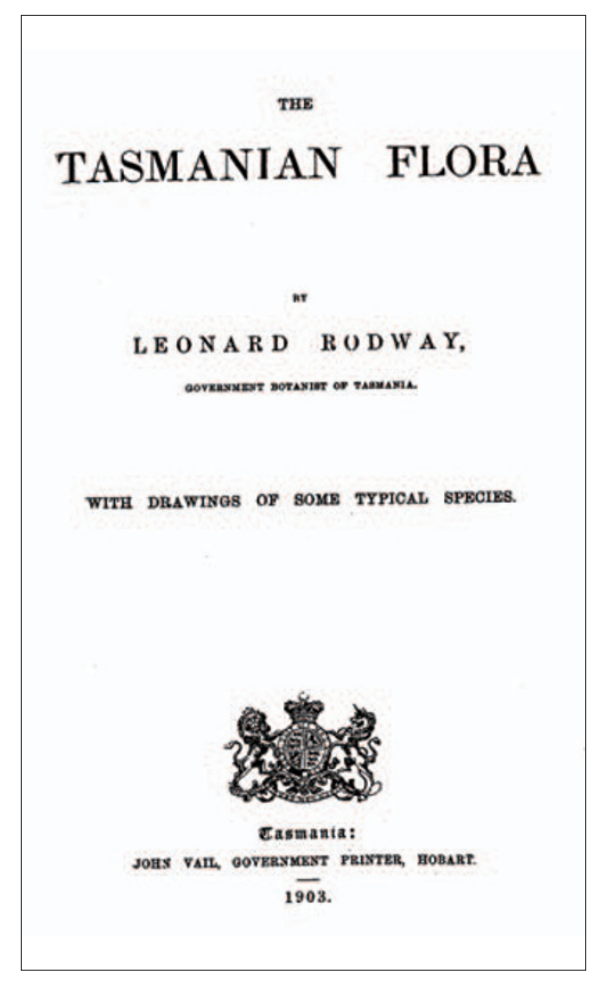

Fig. 6 The title page of The Tasmanian flora, an encyclopaedic work published by the Tasmanian dentist, Leonard Rodway CMG (1853-1936)

His Hobart dental practice, founded in 1884, formed the financial base for his enormous philanthropic and scientific work. It was carried on by two of his five sons. ${ }^{26}$

The genus Rodwaya was raised by Ferdinand von Mueller in 1890 (now sunk and reclassified as Thismia). Rodway's Bent Grass, Deyeuxia rodwayi, Lachnostachys rodwayana, Schoenus rodwayana, and Rodway's Gum, Eucalyptus rodwayi, are enduring memorials of his life and works. A particularly beautiful eponymic memorial to Dr Rodway are the Fairy Lanterns, Thismia rodwayi (Fig. 7), described rather prosaically in formal botanical literature as 'restricted to damp humus, flowering sometimes [even] under the forest litter, and treefern butts in shaded fern gullies in Tasmania, eastern Victoria and new South Wales; a small leafless saprophyte, with creeping vermiform and mycorrhizal root-systems'. ${ }^{26}$ Another descriptive phrase refers to this 'rare and highly remarkable plant' which after prolonged rain glows with internal luminescence and is truly 'Rodway's Fairy Lantern'.

A number of other botanical names record the life and works of Australian dentists. The beautiful pink camellia

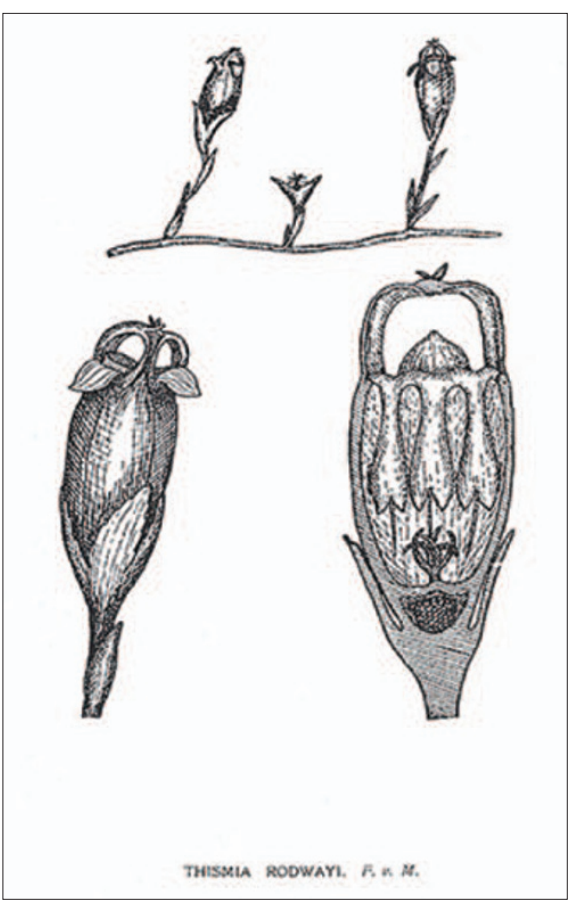

Fig. 7 The hand-drawn diagrams of the flowers of the Fairy Lanterns, Thismia rodwayi, drawn by the Melbourne botanist, Dr Ferdinand von Mueller, who named this new species to honour Leonard Rodway (1853-1936), esteemed Tasmanian dentist

cultivar, 'Dr T. E. Pierson', ${ }^{28,29}$ records the life of Dr T. E. Pierson, a dentist of Hurstville, Sydney. The International Camelia Register describes this bloom as 'a loosely imbricated, formal double, deep rich pink flower, $14 \mathrm{~cm}$ across and 5 cm deep, blooming mid-season to late'. ${ }^{30}$

The mistletoe, Webster's Ixiolaena, Ixiolaena websteri, records the life and works of Dr Leonard C. Webster, initially a pharmacist and dentist for six years in Coolgardie (1888-1894) before his later graduation as a doctor. Dr Webster collected in the Coolgardie environs. ${ }^{31}$ The mistletoes which comprise this genus are the source of birdlime, a highly adhesive extract used by hunter-gatherers to trap birds.

The Australian pelargonium, Helm's Stork's-bill, Pelagonium helmsii, commemorates the life and work of the German-born dentist and watch-maker, Richard Helms (1842-1914). ${ }^{32}$ Helms was extraordinarily versatile and became one of Australia's and New Zealand's best-known naturalists of his day. He travelled and collected on the Darling River and was a member of the Elder Expedition (1891-92) which traversed the Western Desert from South Australia to Murchison in Western Aus- 
tralia. ${ }^{33}$ Helms wrote extensively on the honey-bee, ticks and other parasites, noxious weeds, plant diseases, birds, conchology and anthropology. He discovered new species of plants. Many new species of New Zealand insects and a number of shells were also named after him.

\section{Dentists' names in marine creatures}

A particularly rich repository of enduring simple symbols of the life and works of dentists, throughout the world, is to be found in the scientific names of marine creatures. Dozens of dentists have been so honoured in this way. Many dentists who have had a lifelong and passionate commitment to seashells have contributed much to the scientific disciplines of malacology and conchology. One in particular was Dr Pieter Boddaert (17301796), a Dutch physician and dentist who published extensively on dentistry from the University of Utrecht. Another was Dr Lorenzo Gordin Yates (1837-1909), a dentist and malacologist who emigrated to the United States and whose life and works were recorded in the name of the marine gastropod, Typhina yatesi. ${ }^{34}$

Charles Spence Bate's (1819-1889) name is commemorated in five crustaceans, one of which is Costa batei, so named by the natural historian Brady in 1866.

Thomas Bell (1792-1880) has a crab, Cancer bellianus, named after him. In 1997, the Belgian dentist, Dr Jan dePrez was honoured by the naming of a cowrie, Cypraea jandeprezi, so named by Poppe and Martin in 1997. ${ }^{35}$

\section{Medals}

Eponymous medals comprise some of the most enduring of memorials to dentists. The earliest known dental numismatic items are Roman coins of the reigns of Gordianus (Gordian III) from 238-244 $\mathrm{AD}$ and those of Gallienus (Licinius Egnatius Gallienus) in 253 AD. These coins were minted in Tyre, a Roman colony and portray on the obverse 'Cadmus, son of Agemor, King of Tyre, in the act of killing a dragon or large serpent with a stone'35 (Fig. 1). The fact that the moneyer portrayed a stone rather than a sword can be excused on the fact that the Homeric legend of Cadmus began more than 1,400 years previously. The origin of the dragon probably related to King Draco:

The truth of the story appears to be that there was a King of the Thebans, named Draco, whom Cadmus slew, and of whose Kingdom he took possession. The Tyrians, to show the high antiquity of their city, commemorated the reputed fact by this allegorical type. ${ }^{35}$

There are more than 30 eponymous medals which commemorate Australian dentists. Examples are the Frances Gray Medal and the William J. Tuckfield Prize Medal, each bestowed by the Faculty of Medicine, Dentistry and the Health Sciences of the University of Melbourne. Another is the Bertha Bennett Prize Medal bestowed by the Royal Dental Hospital, Melbourne. Two examples of eponymous dental medals are illustrated (Figs 8 and 9). The R. Fairfax Reading Memorial Prize Medal was struck by the Dental Alumni Society of the University of Sydney in 1950, to commemorate the services to dentistry of Professor Richard Fairfax Reading, Head of the Sydney Dental Hospital from 1920 and first Dean of the Faculty of Dentistry from 1921. The Dental Alumni Society was formed in 1943. The Fairfax Reading Medal is bestowed 'for an outstanding contribution to dental science' (Fig. 8).

A second example is the F. G. Christensen Memorial Medal which is awarded by the Royal Australasian College of Dental Surgeons 'for outstanding proficiency at the Primary Examination for Fellowship of the College'. Professor Frederich George Christensen (1915-1969), was a dental surgeon, teacher and lecturer at the University of Queensland and at the University of Baghdad. ${ }^{36}$ He had been a brilliant student, being awarded the first dental University Medal from the University of Queensland (1939) and later (1954) its second Doctorate of Dental Science. ${ }^{36}$ He served the (then) Australian College of Dental Surgeons in its formative years as a Councillor, Lecturer, Examiner and as Chairman of the Queensland Regional Committee. After four years of planning, the Australian College of Dental Surgeons was incorporated on the 11 September 1970. The 'Royal' prefix was bestowed in August 1972 and the College became the

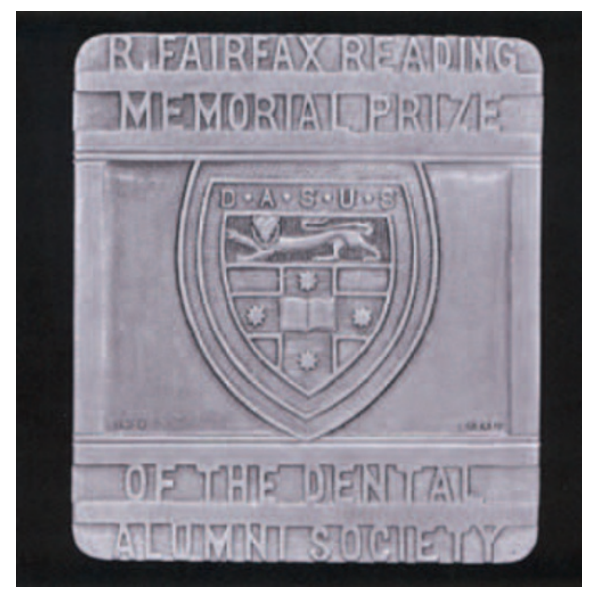

Fig. 8 The R. Fairfax Reading Memorial Prize Medal has been awarded since 1950 by the Dental Alumni Society of the University of Sydney. It commemorates the life and works of Professor Richard Fairfax reading, foundation Dean of the Faculty of Dentistry (University of Sydney) from 1921. Bronze plate, $50 \mathrm{~mm}$ by $58 \mathrm{~mm}, 3.5$ thick, 85 grams, by AMOR of Sydney

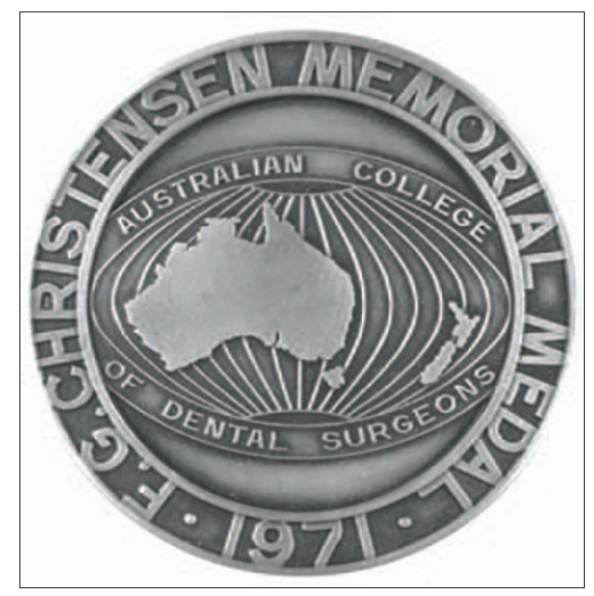

Fig. 9 The F.G. Christensen Memorial Medal of the Royal Australasian College of Dental Surgeons, endowed by a bequest from Professor Frederich George Christensen (1915-1969), of Brisbane. Professor Christensen was a foundation Councillor, Lecturer and Examiner of the College. Pictured is the foundation medal. The RACDS was incorporated as a College on the 11 September 1970. The 'Royal' prefix was bestowed in August 1972 and the College name was changed to 'Australasian' in March 1977. Bronze disc, obverse. $63 \mathrm{~mm} \times 5 \mathrm{~mm}$, 118 grams, by AMOR of Sydney

Australasian College of Dental Surgeons in March 1977. The George Christensen Memorial Medal is a bronze disc, the obverse of which depicts an oblate globe on which are superimposed the maps of Australia and New Zealand (Fig. 9).

\section{Towns and streets}

Communities honour those who have given service to society by the bestowal 
of the civic names of streets and towns. One such example is the Major Jock Clarke Street at Enoggera in Brisbane, named and unveiled by the author on 29 November 1999, as a tribute to Major Jock Clarke, a military dentist held in high esteem.

Captain John Edward Rea Clarke, 'Jock' (b.1916), was one of the first dental graduates from the newly established Faculty of Dentistry at the University of Queensland, in 1938. He served as a Dental Officer with 2/2 Casualty Clearing Station and was one of the military dentists who cared for the entrapped soldiers during the Siege of Tobruk (Fig. 10). Subsequently, he was captured on Java and served with distinction as a Japanese POW until August 1945. After his repatriation he bought Owen Pearn's dental practice in Brisbane and worked as a private dental surgeon for the ensuing 15 years until he accepted an appointment as full time Clinical Lecturer in the Dental School at the University of Queensland.

The bronze plaque in the Major Jock Clarke Street reads:

\section{CAPTAIN JOHN EDWARD REA CLARKE}

Military dentist, soldier of courage and dedicated clinician. He was a leader in the maintenance of hygiene and undertook dental work for over two years serving his fellow prisoners on the Burma-Thailand Railway (1942-1945). His brilliant improvisation on malaria control and hygiene in highly infected cholera and dysentery areas saved many lives.

A particularly important civic memorial to South Australia's first dentist, Dr Robert Hastings Norman (1808-1883), ${ }^{37}$ is embodied in the name of the town of Normanville. Dr Norman's forebears were among the subscribers to the South Australian Colonisation Project of 1834. Born in England, Robert Hastings Norman emigrated to Australia in 1834 and commenced dental practice in Wright Street, in Adelaide later in that year. Norman Street, which runs off Wright Street in the city of Adelaide, was named after him. ${ }^{38}$

Robert Norman purchased land 80 $\mathrm{km}$ south of Adelaide on the coast of the Fleurieu Peninsula where he established the town which today bears his

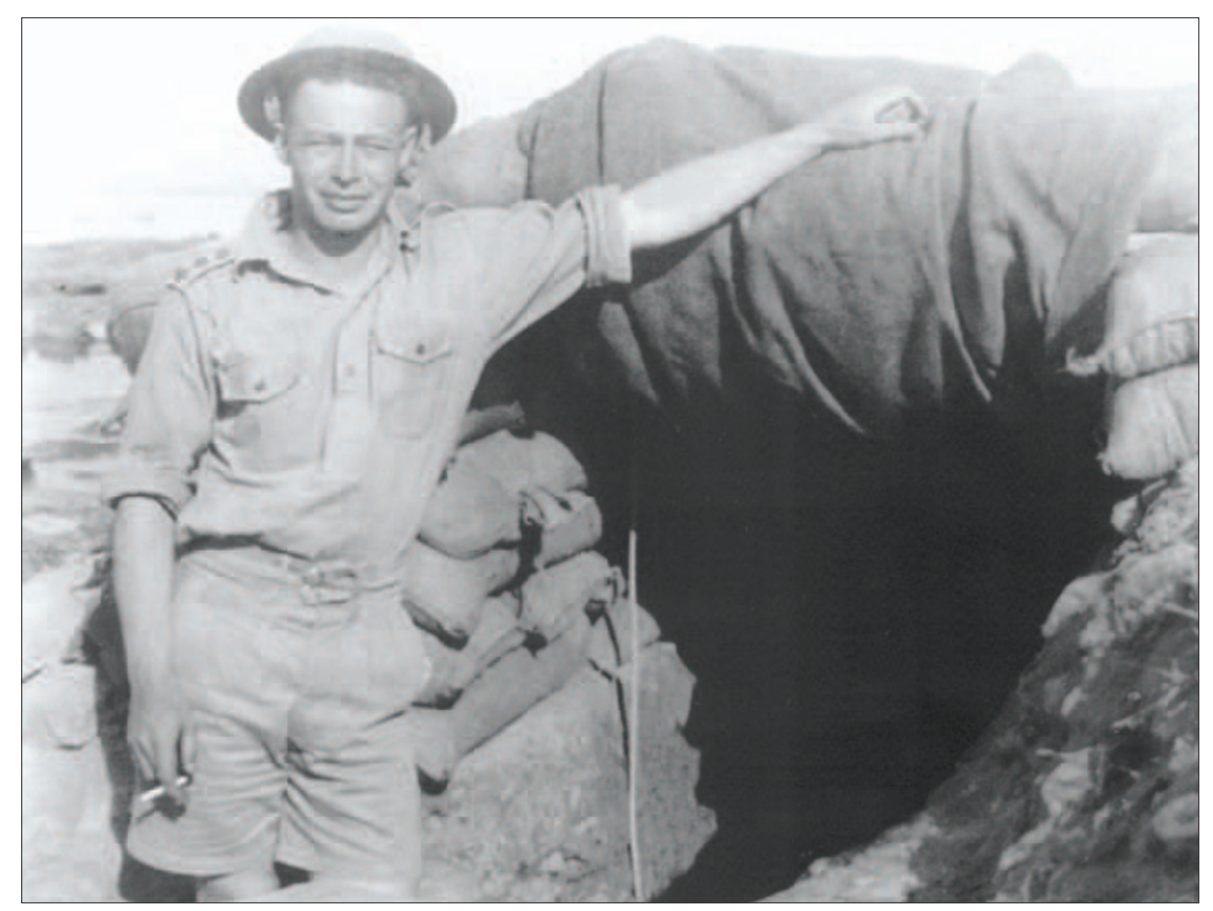

Fig. 10 Captain John ('Jock') Edward Rea Clarke (b.1916), the Dental officer of 2/2 Casualty Clearing Station, at his dental surgery dugout at Tobruk, in 1941. The Siege of Tobruk, Libya, lasted from the 10 April - 27 November 1941. Photograph courtesy of his son, Mr David Clarke, with acknowledgements

name, Normanville (Fig. 11). There he built a blacksmith's shop, church, hotel and houses. Land was also set aside for a police station. He built a mausoleum for his family which is still extant; but it is recorded that:

When the time came and his wife, Sarah, died in 1867, the mausoleum with its vault was full of wine, and she was buried in the surrounding vineyard instead. ${ }^{37}$

Other memorials to this pioneer dentist also exist. There is a hotel 'Norman's Victory Hotel' at Sellicks Hill on the road to Yankalilla. The 'Victory' in Robert Norman's Hotel name does not refer to Nelson's flagship, but to the triumph of eventually having a road built from Victor Harbour to Yankalilla.

Robert Norman's most remarkable achievement was a prosthetic hand he made for a returned soldier, Private Coles. Dentists of the nineteenth century were often called upon to make artificial noses and palates to replace those lost through the gummata of syphilis, but the artificial hand which Norman made was indeed a masterpiece. ${ }^{39}$ Robert Norman carved the prosthetic hand from dugong bone. ${ }^{39}$ It was reported that Private Coles could deal a pack of cards, hand a plate and lift a glass of wine with his articulated hand. ${ }^{37}$ Three of Robert Norman's six sons became dentists. One, Herbert Hayes Norman went to the United States in 1866 and graduated as a Doctor of Dental Surgery with Honours at the New Orleans Dental College in 1871, before returning to South Australia where he practised dentistry for 52 years. Robert Norman's memorials are the town of Normanville and several streets including Norman Avenue which leads to Normanville Heights, a suburb of Normanville (Fig. 12).

Much research remains to be undertaken on the civic memorialisation of Australian dentists.

\section{Conclusion}

The profession of dentistry today has arisen from the widest variety of backgrounds. Dentists emerged from the ranks of goldsmiths and watchmakers, from the world of barbers and patent medicine vendors ${ }^{40}$ and from the ranks of medicine itself. In some parts of the world, particularly in Europe and later in Australia, dentists emerged from the ranks of apothecaries, surgeons and pharmacists.

Irrespective of such origins, the very skilled physical nature of dental work endures. Because of the enduring physical and chemical nature of teeth and 


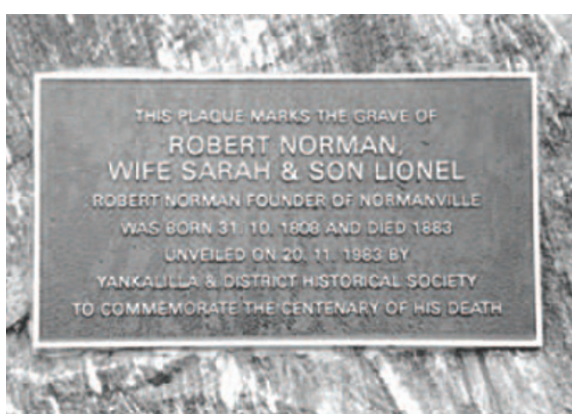

Fig. 11 The bronze plaque commemorating the life and works of Robert Norman (1808-1883) dentist, Shakespearian scholar, swordsman and prosthetic pioneer, after whom the South Australian coastal town of Normanville and several Normanville and an Adelaide Street are named. Photograph, courtesy of Associate Professor Gael Phillips, January 1993, with acknowledgements

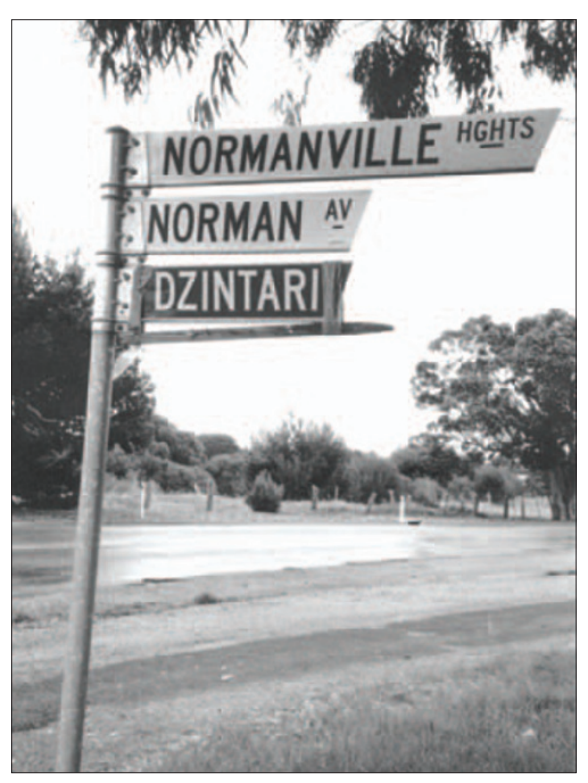

Fig. 12 A signpost at Normanville, South Australia, commemorating the life and works of Robert Norman (1808-1883) a pioneer dentist of South Australia. Photograph, January 1993, courtesy of Associate Professor Gael Philips, with acknowledgements

jaws, and of the dental materials with which one works, much of dentists' work lasts indefinitely. Archaeological evidence from Mehrgarh in Baluchistan, using electron microscopy, has revealed that neolithic dentists working more than 8,000 years ago repaired teeth with stonetipped drills. ${ }^{41}$ This physical resilience is indeed the base of the contemporary specialty discipline of forensic dentistry. However, such endurance and longevity are exploited only when some disaster or crime or mystery (usually requiring the identification of bodies) has arisen.

By contrast, many of us crave to have some proactive creative component to our lives - an often unmet ambition to leave something positive which will interest or delight, which will arouse curiosity or which will inspire those who will follow on. In this context, one occasionally asks the question 'What of our work will endure?' Most strive to balance personal lives between clinical service within the profession of dentistry, and creativity. Many of us feel we never achieve an optimal balance, and most feel they are driven, as servants of the profession, by our clinical responsibility to our patients and to others. Nevertheless, the profession itself and society more broadly does create enduring symbols which will tell something to historians of the long-distant future about the contemporary profession of the art and science of dentistry. Such will be of great interest and value in the future, but very much enrich personal and professional life today.

1. Schachter A. Cadmus. In Hornblower S, Spawforth A (eds). The Oxford classical dictionary, $3^{\text {rd }}$ ed. $p$ 267. Oxford: Oxford University Press, 1999.

2. Garrison F H. Renaissance, revival of learning and reformation. In: An introduction to the history of medicine, $4^{\text {th }}$ ed. Saint Apollonia: 242. Philadelphia: WB Saunders Coy, 1929.

3. Moncrieff A R H. The tragedies of Thebes. I. Cadmus. In: Classical legends. pp 215-220. London: Chancellor Press, 1995

4. Hornblower S, Spawforth A (eds). Spartoi. In The Oxford classical dictionary, $3^{\text {rd }}$ ed. p 1434. Oxford: Oxford University Press, 1999.

5. Dennis P, Grey J, Morris E, Prior R. Royal Australian Army Dental Corps. In: The Oxford companion to Australian military history. p 512. Melbourne: Oxford University Press, 1995.

6. Linnaeus Carolus. Systema Naturae Per Regna Tria Naturae. Tomus I. [10 ${ }^{\text {th }}$ ed]. Holmia, Laurentii Salvii, 1758. [Facsimile Edition published by the Trustees of the British Museum (Natural History), London, 1956].

7. Adler K, Applegarth J S. Bell, Thomas (1792-1880). In: Contributions to Herpetology, Number 5. pp 35-36. USA: Society for the Study of Amphibians and Reptiles, 1989.

8. Cogger H G, Cameron E E, Cogger H M. Varanus belli. In: Varanidae. In: Zoological Catalogue of Australia. Volume 1. Amphibia and Reptilia. pp 126134. Canberra, Bureau of Flora and Fauna, [Aust. Govt. Publishing Service], 1983.

9. Barnard P. Milestones in Australian dentistry. In: History of Dentistry Section, World Dental Federation Congress [Federation Dentale Internationale (FDI)], Sydney, 20 September 2003.

10. Jeannerett $H$. Hints for the preservation of the teeth. Sydney, Printed by R. Mansfield for the Executors of R. Howe. Sydney, W. M'Garvie, 1830.

11. Ford E. Henry Jeannerett and his first Australian book on Dentistry. Aust Dent J 1952; 24: 113-116.

12. Levine S. Australia's first two dental books. Ann Aust Coll Dent Surg 1967; 1: 19-27.

13. Pearn J, Phillips G. The life of Henry Jeanneret
(1802-1886). Pioneer Australian Dentist. With an account of his colonial service and scientific contributions in Australia. Aust Dent J 1996: 41: 260-264.

14. Editor. The Australian (Sydney newspaper). Entries of 23 September 1831 and 7 December 1832.

15. Maiden J H. Record of Tasmania botanists. J Roy Soc Tasmania 1909: 12.

16. Turnbull C. The last of the Tasmanians. pp 220-230. In: Black War. Melbourne: Sun Books, 1974.

17. Pearn J H. Dr Henry Jeannerett (1802-1886). In: A doctor in the garden. p 200. Brisbane: Amphion Press, 2001.

18. Harvey W H. Genus Jeannerettia. In: Nereis australis. pp 20-21. London: Reeve Brothers, 1847.

19. Pearn J H. Dr Frank Tratman (1860-1926). In: A doctor in the garden. p 361. Brisbane: Amphion Press, 2001.

20. Cohen B C. A history of medicine in Western Australia. p 115. Perth, 1965.

21. Kimberley W B. Dr Frank Tratman, JP.MD.MRCS. DPH.LRCP(Eng). In: History of West Australia. pp 90-91. Perth, 1897

22. Editor. Rodway, Leonard, C.M.G. (Tas.). In: Who's who in Australia, $8^{\text {th }}$ ed. 1933-34. Melbourne: The Herald 1933-34: 268-269.

23. Editor. [Obituary]. Leonard Rodway. Chronica Botanica 1937; 3: 60.

24. Editor. Mr L. Rodway Honoured. Hobart Mercury. 1928. News item of 13 September 1928.

25. Rodway, Leonard. The Tasmanian Flora. Hobart, John Vail Government Printer, 1903.

26. Baines J A. Thismia rodwayi. In: Australian Plant Geneva. p 372. Sydney: Society for Growing Australian Plants, 1981.

27. Pearn J H. Frederick Arthur Rodway. 1880-1956. In: A doctor in the garden. p 319. Brisbane: Amphion Press, 2001.

28. Editor. Dr T. [R] [orchographic error] Pierson... Camellia reticulator. Camellia News [Australian Camellia Research Society J.] 1982; 83: 22. [Reg No. 289.]

29. Editor. Dr T. [R] [orthographic error for T.E. Pierson] Pierson. The Camellia J 1986; 41: 27.

30. International Camellia Register. USA, American Camellia Yearbook, [cumulative 1986]: 575.

31. Baines J A. Ixiolaena websteri. In: Australian Plant Genera. p 199. Sydney: Society for Growing Australian Plants, 1981.

32. Baines J A. Pelagonium helmsii. In: Australian Plant Genera. p 275. Sydney: Society for Growing Australian Plants, 1981

33. Chisholm A H. Helms, Richard (1842-1914). In: Australian Dictionary of Biography. Vol 4 18511890. D-J. Gen Ed. D. Pike. p 374. Melbourne: Melbourne University Press, 1979.

34. www.tmbl.gu.se/libdb/taxon/personetymol/index. htm [Updated by Hans G. Hansson@ @tmbl.gu.se; accessed 7 July 2008].

35. Stevenson S W, Smith C R, Madden F W. Cadmus. In: A dictionary of Roman coins, republican and imperial. pp 825-826. London: B.A. Seaby Ltd, 1964

36. Marlay E. A history of dental education in Queensland 1863-1964. pp 178, 179. Brisbane: The Dental College (University of Queensland), 1979.

37. Phillips G E, Pearn J H. 'Oral History' - Memorials to Three Pioneer Australian Dentists. In: Outpost medicine - Australasian studies on the history of medicine. [Proceedings of the Third National Conference of The Australian Society of the History of Medicine, Hobart, Feb 1993]. pp 87-116. Hobart, University of Tasmania and The Australian Society of the History of Medicine, 1994

38. Chapman A. A history of dentistry in South Australia 1836-1936. pp 10-19. Adelaide: Gillingham and Company Ltd, 1937.

39. Editor. [Feature item of Robert Hastings Norman (1808-1883)]. The Advertiser [Adelaide daily newspaper] 1985; 29 April: 2.

40. Hillam C (ed). The roots of dentistry. p 38. London: The Lindsay Society for the History of Dentistry [with Br Dent J], 1990.

41. Cohen P. Open wide. Prehistoric dentists repaired teeth with stone-tipped drills [American Association of Physical Anthropologists]. New Sci 2001; 170: 19 